\title{
Identity and experience: A study of selected female physicians in five provincial states of Mexico
}

\author{
Margaret E. Harrison-BA-Hons, Ph. D.(1)
}

\section{Harrison-BA-Hons ME. Identity and experience: A study of selected female physicians in five provincial states of Mexico. Salud Publica Mex 2000;42:208-216.}

\begin{abstract}
A bstract
The aim of this paper is to analyse the identity(ies) and experiences of a selected group of female physicians in five provincial states of Mexico. In the last 30 years the number of female physicians in Mexico has grown considerably and yet little is known about these women. Data for this work were drawn from two in-depth interviews with 99 female physicians during 1995-1996. In addition, physicians were asked to complete a personal diary to illustrate the nature of their daily experiences over a three-month period; the gap between the two interviews. Analysis reveals female physician identity is shaped by Mexican health care service structures, personal characteristics and goals, and career development choices and opportunities. Association with particular spaces and places influences female physician career development and identity. The multiple identities of these professional women and their lived experiences can result in various pressures and tensions in family and career life. As a result these women make choices about career develo pment; some reassess their career go als given their family and household circumstances and thus their career development may appear to be constrained.The paper concludes by suggesting that changes in Mexican health institutions and the science of medicine may lead to changes in female physician identity.
\end{abstract}

Key words: identity; physicians, wo men; career development; life change events; M exico

\author{
Harrison-BA-Hons ME. \\ Identidad y experiencia: \\ estudio de médicas seleccionadas \\ en cinco estados de México \\ Salud Publica Mex 2000;42:208-216.
}

\section{Resumen}

El propósito de este artículo es analizar la(s) identidad(es) y experiencias de un grupo selecto de médicas en cinco estados de México. El número de médicas ha aumentado considerablemente en los últimos 30 años en México. Aún así se sabe poco so bre ellas. La información para este trabajo proviene de dos entrevistas a profundidad con 99 médicas, realizadas entre 1995 y 1996. A demás, se pidió a las médicas llevar un diario por tres meses (el lapso de tiempo entre las dos entrevistas) para registrar sus experiencias cotidianas de trabajo. El análisis de la información demuestra que la identidad de la médica es moldeada por las estructuras de los servicios de atención a la salud de México, las características y metas personales y las elecciones y oportunidades de desar rollo profesional. La relación con espacios y lugares particulares influye sobre el desarrollo profesional e identidad de la médica. Las múltiples identidades de estas profesionistas y sus vivencias pueden producir distintas presiones y tensiones en su vida familiar y profesional. Como consecuencia, de las mujeres que eligen su forma de desarrollo profesional, algunas de ellas reevalúan sus metas profesionales, tomando en consideración las circunstancias familiares y del hogar, lo que parece restringir su desarrollo profesional. Las conclusiones sugieren que los cambios de las instituciones de salud y de la medicina pueden producir cambios en la identidad de la médica.

Palabras clave: identidad; médicos mujeres; desar rollo profesional; acontecimientos que cambian la vida; México

Material in this paper is drawn for the Economic and Social Research Council (ESRC) of the United Kingdom funded research project: Career and Life Course Experiences of Female Physicians in Mexico. ESRC grant: H52427502095.

(1) School of Environment, Cheltenham and G loucester College of Higher Education.

Received on: N ovember 29, 1999 - Accepted: May 15, 2000

Reprint requests to: Margaret E Harrison B.A. Hons. School of Environment, Cheltenham and Gloucester College of Higher Education, Francis Close Hall, Swindon Road, Cheltenham, Glos., GL50 4AZ, United Kingdom. E-mail: mharrison@ chelt.ac.uk 
$\mathrm{n}$ this paper the identity(ies) and experiences of

female physicians are analysed with particular reference to the relationship between identity construction and life course experiences. A sample of female physicians working in various states and health institutions was studied during 1995 - 1996. Evidence from this study suggests that social structures, physical space, health service structure, personal characteristics and goals, and career opportunities and choices, influence identity construction, as well as short and longterm lived experiences. Any analysis of the complex relationship between identity and experience must be contextualised and embedded in the changing socioeconomic, political and cultural circumstances of particular places, in this case provincial Mexico. This paper explores the tensions experienced by female physicians as they pursue their careers; also, it reviews the range of differences within and between this group of workers. In particular, three case study biographies are provided to illustrate the personal and professional experiences and tensions female physicians can encounter.

There are two reasons for studying female physicians. Firstly, there is a lack of data on female physician employment in provincial Mexico; secondly, as a medical geographer I am aware of the need to incorporate the concerns of feminist geography into an analysis of female diversity, difference, identity and experience, in relation to employment. Over the last 25 to 30 years there has been a considerable growth in the number of female physicians in Mexico ${ }^{1}$ and by 1990 an estimated 30 per cent of the physician work force was female. Studies of female physicians have been limited to work carried out in Mexico City. ${ }^{2,3}$

\section{Context}

Economic development and cultural change, including an expansion in education has resulted in more women wanting to work as well as needing to work. Since the 1982 economic crisis, and with increased consumerism, more women need to work to attempt to maintain a certain standard of living. By 1990, thirtyfour per cent of professionals were female, and in 1994, forty-five per cent of university students were female. ${ }^{4}$ Educational aspirations and opportunities for women may have expanded, but remain spatially constrained by familial, cultural and socio-economic factors despite changes in traditional patriarchal practices. ${ }^{5}$

In the late 1970's and early 1980's two specific schemes were introduced to reach the marginal urban and rural poor of Mexico via the provision of a form of Primary Health Care (PHC). This development led to increased employment recruitment and coincided with the expansion in the number of female physicians exiting medical schools. Health care expansion was short lived; however, as the structural adjustment and debt reduction programmes of the 1980's resulted in reduced funding for health care in the 1990's. ${ }^{6}$ Economic difficulties in the mid 1990's have not improved the situation. As a result, it is claimed that as the status of the profession has diminished professional remuneration has declined relative to other professions, and this may explain why fewer men now participate in health care work. ${ }^{7}$

Statistical data on human resources in the Mexican health sector have become more detailed over the years. However, very few statistics are available by gender. In 1995 there were over 97000 physicians in Mexico. ${ }^{8}$ Institutionally, the social security systems of IMSS (Mexican Institute of Social Security) and ISSSTE (Institute for Social Security and Services for State Workers) command more personnel, including $60 \%$ of physicians. There is an inequitable distribution of physicians among the states of Mexico, with a relative 'abundance' in the north -industrial- urban areas, and a relative 'impoverishment' in the south -agricultural- rural areas. Also, the Federal District and the State of Mexico account for over $34 \%$ of physicians.

\section{Methodology: Data and fieldwork}

Material presented in this analysis comes from a larger study on career and life course experiences of female physicians in Mexico. ${ }^{*}$ Qualitative research methods were employed to investigate this group of female professionals. Initially four states were designated as study areas; this was later increased to five. The initial four study states: Nuevo León, Oaxaca, San Luis Potosí and Veracruz, were selected on the basis of level of economic development, medical-health status ${ }^{9}$ and having a university medical school. The additional study state-Sonora- does not have a medical school. This state was incorporated because it was recognised that assumptions were being made about female physicians working in a state without a medical school and data were required to verify or nullify these assumptions.

The target population of female physicians is defined as those who have received formal university

\footnotetext{
* Material in this paper is drawn for the Economic and Social Research Council funded research project: Career and Life Course Experiences of Female Physicians in Mexico. I was the principal researcher in the project but was assisted by a research assistant. Fieldwork took place from January to June 1996.
} 
medical education and are practicing their profession in either the public or private sector. All potential study candidates were contacted via their work place. Once contact was established with a health institution, a stratified sample was compiled, consisting of physicians working in hospitals, health centres and administrative offices. The director of each unit gave permission for the study to be undertaken and (s)he identified possible study candidates. Obtaining the permission of each health unit's director may well have influenced the study results. Those physicians interviewed may have been like-minded, or physicians the director believed suitable, or physicians that directors thought would provide a positive image of their work environment, colleagues and institution, or indeed physicians with time to participate in the research. Whatever the selection reasons, all candidates but one were willing to participate in the study.

A total of 99 physicians was interviewed. Ninetyone physicians were contacted via a health institution, (50 in the IMSS, 25 in the SSA -Health Secretariat or Ministry of Health- and 16 in ISSSTE); the remaining eight physicians were in private practice. The 1986 and 1993 Instituto Nacional de Salud Pública (INSP) studies ${ }^{1, *}$ indicated that very few female physicians worked in the private sector, hence the reason why only eight private physicians were interviewed. In fact several physicians working in public institutions also worked in the private sector. $\ddagger$ Two rounds of interviews were carried out. $\S$ The first interview was carried out in the work place based on a questionnaire. Themes covered in the questionnaire included: relevant personal details, family background, medical school training, mobility, career development choices and opportunities, and personal goals. The location of the second interview was either the work place, home or some 'neutral' site. There was a three-month gap between the two interviews; during this period interview candidates were asked to complete a diary. It was hoped that study candidates would record aspects of their daily and weekly life experiences in the diary and from this a better picture of the identity and experience relationship

\footnotetext{
* Robledo-Vera C. La feminización de la profesión médica en México a principios de los noventa. México, D.F.: El Colegio de México, 1996 (mimeo).

$\ddagger$ A common practice in Mexico due to low pay levels in the public sector.

$\S$ The 18 physicians studied in Sonora state were only interviewed once. Of the remaining 81 physicians, seven were not interviewed twice. Three had moved away from their posts or could not be contacted, one had died, and three did not wish to be interviewed again.
}

could be obtained. The second interview focused on personal and career developments within the intervening three months; physicians had the opportunity to comment on diary entries and expand on matters discussed in the first interview. Also, the second interview explored the physician's perception of her role in Mexican health care as well as any problems, constraints and difficulties she faced in her career and personal life.

A brief summary of the first interview is given to demonstrate the key characteristics of the physicians. This information provides a background to the substantive part of this paper -an analysis of the nonquantifiable issues of lived experiences, career development decisions and other factors that influence identity construction. Some of these issues are highlighted in three case-study biographies provided in the penultimate section of the paper.

When evaluating the use of interviews as a source of data, the researcher should consider his/her own position as an insider or outsider in the research process. Whatever motivates a researcher to investigate a topic, the researcher should recognise the real difficulties in attempting to represent his/her subjects; in this case female physicians. A researcher may be blind to the most obvious, assume an understanding of a situation, or fail to hear the message clearly. Thus, the interpretation of these women's accounts and experiences can only be partial.

\section{Construction of identity}

Identity is dynamic, constructed, actively created and recreated, ever changing and negotiated; there is no one single female identity but rather many identities which change over time. ${ }^{10,11}$ An individual's identity is created by many varied complex factors, which crosscut one another in time and space. In fact, a person possesses a multiple identity because of the different roles (s)he may hold at any one time in relation to family, work place and society, among other things. ${ }^{12}$ Identity is founded on the everyday 'ordinary' repetitive actions and events of life ${ }^{13}$ as well as on the extraordinary unexpected events. An understanding of the relationship between identity and experience is enriched by considering routines, rituals, practices, and unexpected events.

It is McDowell ${ }^{14}$ who recognises that 'The work of constructing an identity is never complete, involving struggles and resistances, as well as acceptance, pleasure and desire'. A person defines him/herself -and is defined by others- by class, race, age and profession, ${ }^{15}$ and a person's experiences in life will reinforce or 
challenge his/her sense of identity based on these factors. Thus, an awareness and understanding of everyday lived experiences is crucial to constructing identity. The sense of multiple identities suggests variety and difference but also pressure and tension in an individual's life. An individual who constantly faces different demands on his/her use of time and the incompatibility of life roles may cause tension and possibly a crisis of identity.

Experience and identity must be contextualised in time and geographic space, for the lives of most women are spatially fixed. ${ }^{16}$ Association with places, via either spatial fixity or migration, is part of a person's life course experiences. ${ }^{17}$ Each person is located in physical space and social space and many people define themselves by where they are or come from, as well as where they are located in any social hierarchy. These ideas of identifying oneself with a place and 'knowing' one's place in a social structure are powerful forces in structuring an identity.

In studies of Mexico the traditional gender ideals of machismo* and marianismo $0^{\ddagger}$ have been widely used to explain gender roles in the workplace and home. ${ }^{18-21}$ However, Hondagneu-Sotelo ${ }^{5}$ claims 'machismo and marianismo are ideological constructs that may inform people's actions, but they are not themselves actual patterns of behavior'. She goes on to state 'The daily lives of contemporary rural peasants and of workingclass and middle-class urban dwellers in Mexico do not rigidly conform to traditional patriarchal cultural ideals'. The strength of concepts like machismo and marianismo have been eroded and as a result the 'conventional' roles for men and women have been realigned and challenged. Similarly, LeVine states that 'Radical innovations affected family life and relations between husbands and wives ... (and) affected women as social beings' ${ }^{\prime 22}$ In this study, the ideals of the Mexican patriarchal culture are explored to see if the lives of professional women are restricted by these cultural ideological values. Are Mexican female physicians dependent, subordinate, and the main homemaker and child carer in the family while participating in paid employment? And, does the stereotypical image of the female physician, as daughters of middle class families, ${ }^{1}$ still persist?

\footnotetext{
* Machismo - male assertiveness. Hondagneu-Sotelo states: ' Machis$m o$ calls for men to be sexually assertive, independent, and emotionally restrained, to wield absolute authority over their wives and children, and to serve as family breadwinners'.

‡ Marianismo - female submissiveness. Hondagneu-Sotelo states: 'marianismo is modelled on the Catholic Virgin Madonna, and prescribes dependence, subordination, responsibility for all domestic chores, and selfless devotion to family and children'.
}

\section{Female physicians in Mexico: Construction of identity and experience in the life course}

In 1986, 23 per cent of physicians were women, 88 per cent of whom were less than 40 years of age, and 45 per cent held just one medical post, usually a salaried position within the public sector. ${ }^{23}$ A preliminary summary of the INSP 1993 survey* indicates that an increased proportion of physicians ( 28 per cent) were female. The age distribution of physicians had increased; by 1993 twenty per cent of female physicians were between the ages of 40 and 49 . Robledo* suggests that 57 per cent of female physicians come from the middle and upper class and far more female than male physicians had a professional educated father.

Three key aspects of female physicians lives are reviewed: personal characteristics and goals; employment and health service structure; and career development opportunities and constraints. These aspects of female physicians' lives are used to explore identity construction and contribute to an understanding of the relationship between identity and experience. The study also discusses the tensions, regarded by $\mathrm{McDowell}^{14}$ as inner conflicts within identity construction, that female physicians experience in their daily lives, as well as throughout their career and personal development. Tensions may be perceived as the challenges and demands made of female physicians, which force them to make choices and thus emphasise or suppress different identities. Moreover, a consideration of tensions should further our appreciation of the importance of difference amongst physicians.

\section{Personal characteristics, career develop- ment and goals}

Female physicians are largely middle-aged and come from middle class backgrounds. For example, 89 per cent were between the ages of 30 and 49 , the age range of the physicians was 25 to 68 years of age and few were interviewed in the lower age bracket (less than 30 years of age). Forty-three per cent had professional fathers and a further 16 per cent had fathers recorded as commercial traders. ${ }^{\ddagger}$ Female physicians’ partners were nearly all professionals, many were also physicians.

\footnotetext{
* Robledo-Vera C. La feminización de la profesión médica en México a principios de los noventa. México, D.F.: El Colegio de México, 1996 (mimeo).

‡ This could mean many things from street trading to owning several shops.
} 
A career in medicine was chosen because of aptitude and ability as well as a desire to serve and care for people. However, parental encouragement or directive, family example, and personal desire to better oneself, were instrumental in determining career choice. Since all physician participants studied medicine immediately after leaving high school, parental (usually patriarchal) support was considered of vital importance. Birth order and social hierarchy, as well as physical geographic location, influenced what was studied, when, where and why.

A particularly interesting feature is the spatial stability and lack of inter-state migration during the life course. ${ }^{24}$ Two-thirds of physicians were living and working in the state where they had been born. Eighty per cent were working in the state where they studied for their medical degree. Female physicians have close ties to the place where they train. Place acts 'as a source of belonging, identity and security'. ${ }^{25}$ To this is added the cultural context; in Mexico students are normally expected to study at their natal state university. Whilst at university most students are highly dependent on their families for financial support, and may call upon family and friends to help secure temporary vacation work. Students unable to study locally, either because there is no university medical school, as in the case of Sonora, or because of excess local demand, must train in neighbouring or more distant states. In the case of Sonora, 8 out of the 18 physicians interviewed were natives of the state and they went to train in places where they had family or friends; their choice of medical school was heavily influenced by parental dictates.

Finally, in terms of personal goals, all interviewees were asked to record what they hoped to achieve in their profession. Just under one third of physicians (31) emphasised economic necessity, i.e. maintaining a certain life-style, in conjunction with personal goals and aspirations. All respondents wished to 'succeed' in their profession and most felt called to help the community. It is important to know that well over 50 per cent of physicians shared equal or superior salary and career status as their partners.

\section{Employment and health service structures}

Experience in the medical labour market shapes the identity of each medical graduate. While training, most undergraduates obtain a good knowledge of the main public health institutions. Networks established while training, or family connections, may help gain employment. Most physicians seek work in their natal state after training. Thus, medical training and the one-year social service programme reinforce the attachment to the natal state. For one physician in Oaxaca, her father was a physician with the IMSS in Oaxaca city and his medical contacts proved helpful in securing employment for her with the IMSS; she never applied to the SSA or ISSSTE for work.

Employment in the largest and most prestigious public health institution, IMSS, was popular and is perceived as providing a certain status. Acceptance or rejection by a public health institution may have a major impact on identity formation. Rejection by the IMSS may be seen as failure, while acceptance of work with the SSA in certain locations might be seen as tacit acknowledgement of low value, status and worth. The size of the medical workforce, particularly in primary level centres, can influence identity construction. IMSS primary level centres usually have more than 10 physicians working at once. Both the ISSSTE and SSA operate one-nurse, one-physician health centres, as well as larger units. In these different circumstances, opportunities and constraints clearly operate. Those in larger groups may forge a corporate identity as well as engage in competitive and collaborative professional development experiences whereas the lone worker may feel isolated, remote and undervalued by the institution.

Even obtaining work with a public institution does not guarantee permanent employment. Because of insufficient funding the bolsa de trabajo (job register) is limited or even static. As a result, many professionals take up temporary contracts. Some physicians remain on temporary contracts for years. For example, one interviewee, a paediatric neuro-surgeon, had worked in one institution for three years on three-month temporary contracts. It was claimed her specialist hospital simply did not have sufficient funds to offer her a permanent post. The failure to secure a permanent contract is reluctantly accepted by many physicians. Also, temporary workers may find themselves under pressure to work longer hours with the offer of a permanent post presented as the incentive. Once work is secured with an institution, female physicians remain loyal to the institution. Eighty per cent of interviewees had remained with the same institution since starting work, and with many remaining in the same post. Loyalty to a particular institution, as well as job stability and security, appear important to female physicians and suggest a certain identity.

Another aspect of health institution structures which influences identity development is whether a physician opts to concentrate on patient care or becomes channelled into administrative work. Administrative posts may attract more pay, require human 
resource management skills, and provide a greater opportunity to advance one's career. Some interviewees claimed to be disinterested and not attracted by administrative posts, although few willingly disclosed if they had sought such work and been rejected. Others (usually the younger physicians) had as yet not had the opportunity to apply for administrative posts. The demands and nature of administrative posts, and the desire to work with patients, have been used to explain why few women seek such work. Female physicians can and do seek career advancement via acquisition of more than one job. The prestige that comes with either working for more than one institution or running one's own private clinic also suggests a different character trait and identity than holding an administrative post.

\section{Career development choices, opportunities and constraints}

The decision to pursue a speciality or not creates a distinctive divide within the medical profession. Nonspecialists, who are predominantly female, ${ }^{1, *}$ are stigmatised and possibly seen as inferior. Over two thirds of interviewees had a speciality; the most common speciality was family medicine. Female physician interviewees recognised the need of a speciality given the high level of unemployment in the profession and the highly competitive nature of the employment market. The level of speciality training is contrary to what Frenk ${ }^{23}$ discovered in his 1986 study. As stated in the methodology of this article, the researcher relied on health institutions directors to identify interview candidates. Directors may well have chosen highly qualified staff for interview to emphasise the quality of his/her staff. In the 1990's the public sector health budget decreased; consequently the number of physicians the public sector health institutions can employ on a permanent contract has not dramatically increased. At the same time, the medical school output statistics have remained relatively stable. ${ }^{4}$

Female physician identity is influenced by various opportunities and constraints in the profession. Networks established inside and outside work may be helpful for sustaining a physician's career development, in terms of ongoing education and training and the establishment of a private consultancy. The association of female physicians which operates in most

\footnotetext{
* Robledo-Vera C. La feminización de la profesión médica en México a principios de los noventa. México, D.F.: El Colegio de México, 1996 (mimeo)
}

states gives both social and educational support to physicians. This association may not help career advancement directly but may help physicians establish a corporate identity. Bias towards the IMSS in the association (as observed in Oaxaca, Sonora and San Luis Potosí) may represent the divisions that exist between the health institutions. Working for any one of the three major public health institutions creates a certain image and influences physician identity formation.

The daily experiences of female physicians in Mexico demonstrates that they live and work in constrained spatial environments. The location of health units, availability of work, and personal commitments all come together to limit career choice. Single independent physicians, who theoretically might be thought the most able to pick and choose where they work, in fact locate in places near to family or friends. Also, physicians with over 10 years of career experience have a tendency to gravitate back to their parental home often to be closer to or care for elderly parents; this was the case for at least six interviewees.

Dramatic unforeseen events and experiences shape one's identity, role and character just as much as regular everyday routines and activities. Dramatic events may be specific to an individual or felt by a group of people or the whole of society. The Mexico City earthquake of 1985 had a major impact on the lives and identities of the health workers in several major hospitals in the city. A personal tragedy can have profound consequences for the individual, whereas an economic shock -overnight devaluation-can affect everyone. For example, as a result of the early 1980s financial crisis one interviewee returned to Mexico from Spain where she had been undertaking speciality training. Her experience in Spain made her realise she could work outside her natal state of Veracruz; she moved to work in Nuevo León. Foreseen events like health service restructuring can have a dramatic impact on physicians lives and challenge roles and identities.

\section{Female physician identity and experiences: Tensions}

The multiple identities of these physicians, as professional, leader, co-worker, colleague, parent, child, partner, student and employer (of domestic help) etcetera, can put pressure on these women. Trying to play out their many roles at any one time can inevitably lead to tension and potential conflict. To speak of the dual role of women is an underestimation of their life and career commitments. Whatever the circumstances of these women, single and living at home, single parents, mar- 
ried with or without children, widowed or independent, all are committed to their profession and none are looking to move out of medicine despite the declining value of their salary, and the increasing work-load they faced due to economic cutbacks. Such circumstances obviously affect the daily lives and work patterns of these physicians, and may influence career development.

Interview and diary material reveals the complexity of several personal situations; individual circumstances demonstrate possible tension areas. For example, to register a physician as 'married' fails to recognise whether she is living with her partner seven days a week. If she is not, she may well be taking on many roles and identities, some of which may be hard to relinquish once her partner returns. For these physicians finding time to write a diary was difficult because of the multiple demands made on their time. Other physicians, often those in a stable family situation, saw their lives as routine and 'ordinary' and did not believe their diary could be interesting but rather repetitive and boring. Keeping a diary requires specific personality characteristics such as determination and consistency as well as a willingness to open-up and reveal oneself within the text. Many physicians found the task difficult yet 47 out of 81 diaries were returned; 19 diaries were completed in detail.

The majority of physicians had relatively 'stable' household circumstances and yet one should not assume their lives are necessarily any easier than an 'unstable' household. For example, the physician who is a wife, mother of four, with an active social life, may work from 8 a.m. to 2 p.m. in one institution, and have a private practice between 4 p.m. and 7 p.m. In addition, she may work every other night in a public emergency clinic. Physicians with help in the house -over half of the interviewees- undertake many household activities such as washing and shopping. Most hired help does the cleaning, preparing meals and caring for young children for a few hours. Most saw members of their extended family (parents, brothers, sisters etc.) weekly, and often much more regularly. Actual daily physical mobility, as opposed to long-term migration patterns, did not appear a constraint on these women. Over 76 per cent of physicians had access to a car. Few saw their daily lives constrained by space or time, distance was only a constraint if a physician had two jobs. Time might be considered a constraint yet the stretching of the day to accommodate everything is a common occurrence. It is fascinating and informative to see how a physician plans her use of time and space between work, family, friends and professional development commitments.

\section{Three biographies}

Three case studies of physicians are presented to illustrate the lived experiences of physicians, highlight possible tensions, and demonstrate how identity and experience are related.

\section{Interviewee A - Nuevo León}

Interviewee A is a widow who works for the SSA. When first interviewed she was the overall administrative coordinator of one SSA sub-area of Monterrey and a University lecturer. She is a mother of two adult children -both were still living at home- and her elderly mother lives close to her. She gives her identity as someone from Monterrey, born and brought up there, and apart from brief periods away she has always lived there. She studied at Monterrey for family reasons; her widowed mother could not support her to study elsewhere. Whilst at university she met her future husband, a physician, they married once he qualified. She undertook her first specialist training in Mexico city with the SSA, her employer.

Her experiences of medical profession training and career development are such that she believes women have to prove themselves by obtaining better results than men and demonstrating an ability to cope with two jobs: career and family. She does believe things have gradually changed for women. At a time when she was newly married and after her first speciality, she was given the opportunity to obtain an additional qualification but she nearly 'dropped out' due to pressures on her time as a mother and professional. Her husband encouraged her to continue.

In her second interview she revealed that very soon after the first interview she started to seek work elsewhere. Indeed she said the first interview made her re-evaluate her life, career and future. She was offered a position in a remote part of rural Nuevo León (she had no experience of working in the rural areas of the state) and accepted it. At the time of the second interview she did not identify with her new area; she claimed she would like to know the people and customs of the area but she is drawn to Monterrey each weekend because of her mother, family and friends. However, she did say she thoroughly enjoyed learning about life in rural Mexico, she valued the peaceful nights, the ability to walk to work, but she also recognised the stamina needed to make long journeys to visit all her medical units. Interviewee A is a committed medical administrator; she rises to a challenge and if tension exists in her life it is partly due to her desire to succeed. 


\section{Interviewee B - San Luis Potosí}

This physician was born and brought up in San Luis Potosí: the state where she now lives and works. She is married to a physician and has four children. In her early education she wished to study engineering but her father chose medicine for her. She claims she has not regretted fulfilling her father's wish. She met her husband at university; he also comes from San Luis Potosí. They both work for the IMSS but in different health centres in the city. They have a private practice as well. She married just before starting her social service year and by the end of the year had a baby daughter. Her family helped care for her daughter while she completed her social service. After social service, her plan was to study for a speciality in paediatrics; however, she had to reassess her career due to family circumstances and finally opted to specialise in family medicine, training with the IMSS in the state of San Luis Potosí. She did not express any anger or regret at what she had to accept in terms of career development and over the years she has come to realise the benefits of working in family medicine.

Interviewee B took the maximum maternity leave allowance when her children were born. It is Frenk ${ }^{23}$ who suggests female physicians either curtail their career due to motherhood or take an extended period of time out to raise the family. There is no evidence within this study population to support either claim. Interviewee B is a sub director of an IMSS health centre and her long term goal is to be an IMSS health centre director in San Luis Potosí city -according to her it can be nowhere else. Thus her career goals and aspirations are restricted to her home city.

During the three-month gap between interviews she completed a diary. On a daily basis she has to care for her family, hold down two jobs, keep in touch with her parents, run the home and oversee her paid home help, maintain her friendships and when possible keep up to date with her speciality. Tensions arise, as seen in the diary, when she feels the burden of her daily routine. For example on more than one occasion she questioned what her husband did in terms of help in the household. The suggestion within the diary is that she is the prime mover in the home; she is organiser of home and family activities. Her work is such that she may well attend professional courses at the weekends, which put further strain on relationships and forces her to choose between her roles/identities and thus emphasise one above others. Here is a female professional with many daily tensions, and a busy life-style and a complex multiple identity.

\section{Interviewee C - Oaxaca}

This physician is single and was born and brought up in Chiapas. She comes from a family of seven children. She left Chiapas aged 12 to go to school and continue her studies in Oaxaca, including attending medical school in Oaxaca city. Since qualifying she has stayed in Oaxaca because that is where she could obtain work, she does not yet have a permanent post. Given that she is just starting out on her career, her experiences of life and work are fewer than those of Interviewee A and $B$, yet her situation is no less important. She does not have her own car like the other two and therefore her daily mobility is more limited. Her everyday life consists of work, contact with patients and colleagues, and carrying out her personal leisure activities.

Currently, she works in a small SSA rural health centre about $50 \mathrm{kms}$. from Oaxaca city. From time to time she will give a private consultation in her home. She is not looking for further work because she wishes to undertake a speciality in paediatrics and she is preparing for the speciality examination. Her graduate friends form an important part of her life, the nucleus of her social life. In particular, these friends motivate her to study; several of her contemporaries are also preparing for the speciality examination. She was reluctant to participate in the study, and thus her answers were brief and with little elaboration. Given that she is starting out on her career and her single status, this might imply a less complex life. Few family demands are made on her time and she possibly has a less stressful life with fewer tensions. This case study demonstrates that there are young, shy physicians and their experiences are equally relevant to an understanding and appreciation of identity construction.

\section{Conclusion}

This analysis has revealed the complexity of female identity, and the differences and similarities amongst and between female physicians. Over half of the interviewees did come from a middle-class background and certain underlying Mexican cultural ideological values prevail. Daughters of middle-class professionals see their role as both professional and mother: female physicians work in the caring and nurturing profession and do not challenge the stereotypical role of women in Mexican society. Indeed the feminisation of a declining status profession (medicine) does little to alter the case of female subordination. In addition, the daily lived experiences reveal, as exemplified by Interviewee B, most women still take on the larger burden of child care and homemaking. 
The relationship between identity and experience is highly complex. There is no one female physician identity, but within the study group there are similarities. Spatial stability and loyalty to institution appear common features. Despite the pressures and tensions at work and in daily lives, not one of the study group wished to leave medical practice. Career path development is tightly prescribed, and at a time of rising unemployment in the profession and the harsh national economic circumstances, most physicians aim to obtain as many qualifications both before and during their paid working lives. Those starting out in their careers, like Interviewee $C$, know the value of obtaining a speciality. Yet, the experiences of everyday lives, both at work and outside work, force these women to make certain choices. Choice is constrained by gender, class, location, age, family as well as the boundaries imposed by health institutions.

Most female physicians considered their lives to be routine and mundane; many failed to complete a diary because they found little changed or altered in their lives on a weekly and monthly basis. Yet the ordinary and extraordinary experiences in life contribute to identity construction. The tensions in daily career and family life shape identity; these tensions which vary over time represent the problematic element in the relationship between identity construction and experience. Female physician identity can be a melange of many varied facets. Personality and every other aspect of a physician's life is actively responding 'to contested political, economic and social power relations'. ${ }^{11}$

Female professionals face pressures and tension but are also placed by themselves, others and institutions in vulnerable positions. This is of particular concern when Mexico has high levels of medical unemployment and trained professionals are not guaranteed a job: professionals are expendable. Such precarious and vulnerable positions must influence identity construction. Acceptance of certain situations i.e. temporary employment, can develop personal characteristics of perseverance and compliance. Many interviewees working for the IMSS were deeply concerned about their futures. Changes in health institutions and medicine may lead to changes in female physician identity. Only the adaptable, strong and possibly those willing to break away from family ties will secure posts and advance their careers. Membership in an association of physicians may help individuals face change, uncertainty and vulnerability, while the excluded may be professionally and spatially isolated, more vulnerable, and have less chance of career enhancement, but possibly be identified as possessing a strong, independent identity.

\section{References}

1. Frenk J. La profesión médica en las áreas urbanas de México: composición demográfica y origen social. Gac Med Mex 1990;126:92-101.

2. González de León AD, A guirre D, Pacheco-Peña L. La mujer y la profesión médica en México. En: SallesV, McPhail E, ed. La investigación sobre la mujer: informes en sus primeras versiones. Serie Documentos de Investigaciones núm. I. México, D.F.: El Colegio de México, 1988.

3. Harrison M.E.A doctor's place: Female physicians in Mexico DF. Health Place 1995;1:101-111.

4. Asociación Nacional de Universidades e Instituciones de Educación Superior. Sistema N acional de Información para la Educación Superior. Database. México, D.F.:AN UIES/SEP, 1995

5. Hondagneu-Sotelo P. Gendered transitions. Mexican experiences of immigration. Berkeley(C A): University of California Press, 1994:9.

6. Frenk J, Knaul F, Lozano R, Murray CJL, Bobadilla JL, Fernández $S$ et al. Economía y Salud. Propuestas para el avance del sistema de salud en México. México, D.F.: Funsalud, 1994.

7. Shields D. C rece la participación de la mujer en la ciencia. El $\mathrm{N}$ acional 1990 abril 20:5.

8. Secretaría de Salud. Bo letín de Información Estadística, Sistema N acional de Salud. México, D.F.: SSA, 1996.

9. Secretaría de Salud. Encuesta N acional de Salud II. México, D.F.: SSA, 1994.

10. Bondi E. Locating identity politics. En: Keith M, Pile S, ed. Place and the politics of identity. Londres: Routledge, 1993.

11. Larner W. Theorising difference; in Aotearoa/N ew Zealand. Gender Place Culture 1995;2:177-190.

12. Harrison ME. Images of the third world:Teaching a geography of the third world. J Geography Higher Educ 1995;19:285-297.

13. Pratt $G, H$ anson S. G eography and the construction of difference. $G$ ender Place Culture 1994;1:5-29.

14. MCD owell L. Spatializing feminism. En: Duncan N, ed. Body space. Londres: Routledge, 1996:41.

15. Madge C. Boundary disputes: Comments on Sidaway (1992). Area 1993;25:294-299.

16. Pratt G, Hanson S. Women and work across the life course: Moving beyond essentialism. En: Katz C, Monk J, ed. Full circles: Geographies of women over the life course. Londres: Routledge, 1993.

17. W omen and Geography Study Group. Feminist geographies. Harlow: Longman, 1997.

18.Azipe L.W omen and development in Latin America and the $\mathrm{C}$ aribbean. Development Dialogue 1982;(2):74-84.

19. Chant S. Single-parent families: Choice and constraint? The formation of female-headed households in Mexican Shanty Towns. Development Change 1985;16:635-656.

20. Moser $C$. The impact of recession and structural adjustment policies at the micro-level: Low income women and their households in Guayaquil, Equador. En: UN ICEF, ed. Invisible Adjustment. N ew York:UN ICEF A mericas and C aribbean Regional 0 ffice, 1989;vol. 2:137-162.

21. Chant S.W omen and survival in Mexican cities. Manchester : Manchester UP, 1991.

22. LeVine S. Dolor y alegría.W omen and social change in urban Mexico. Madison: University of W isconsin Press, 1993:5.

23. Frenk J, Alagon J, N igenda G, Muñoz-del Río A, Robledo C, VázquezSegovia $L$ et al. Patterns of medical employment:A survey of imbalances in urban Mexico. Am J Public Health 1991; 81: 23-29.

24. Harrison ME. Female physicians in Mexico: Migration and mobility in the lifecourse. Soc Sci Med 1998; 47: 455-467.

25. Massey D. Space, place and gender. Londres: Polity Press, 1994. 